\title{
Ankle Sprain: The Risk Factors in Athletes
}

\author{
Gabriela Souza de Vasconcelos* \\ PhD Sudent, Universidade Federal de São Carlos (UFSCar), Brazil \\ *Corresponding author: Gabriela Souza de Vasconcelos, PhD Sudent, Universidade Federal de São Carlos (UFSCar), São Carlos, SP, Brazil
}

Submission: 悳 May 26, 2018; Published: 眥 May 31, 2018

\section{Introduction}

The ankle is among the sites most affected by acute and chronic injuries in athletes and physically active individuals [1,2]. They are especially prevalent in sports requiring frequent jumping, directional changes and pivoting such as basketball, football, soccer, handball, netball, volleyball and fencing $[1,3,4]$. Ankle sprains often result in persisting limitations to the joint, like pain, swelling, disability, dysfunction, time lost from activity, the requirement for treatment, and economic burden [5-8]. Athletes who sprain their ankle are prone to reinjure the same ankle, with recurrent ankle sprains commonly leading to chronic instability $[7,9]$. Chronic ankle instability is a term used to describe these persisting limitations this is a risk factor for future sprain [6,10-12].

Thus, to reduce the incidence of ankle sprains and their co morbidities in athletes, risk factors should be identified to facilitate classification of players who are at increased risk as well as to inform effective prevention strategies [13]. Besides the chronic ankle instability, some factors like a failed single leg balance test [14], altered gait biomechanics [15] and reduced dorsiflexion range of motion [16], also are identified as risk factors for ankle sprain. The Star Excursion Balance Test (SEBT), that is commonly used to evaluate the dynamic neuromuscular control, is predictive of lower limb injury in athletes of basket ball [17]. Some studies as Attenborough et al. [18] and Hertel et al. [19], have used SEBT to assess risk factors for ankle sprain and have identified that a posterior-medial reach distance in the SEBT is one this factors. And de Noronha et al. [12] found that better performance in the posterior-lateral direction of the SEBT was protective against ankle sprains in active university students.

Ridder et al. [13] to investigate the role of proximal hip strength as a risk factor for lateral ankle sprain injuries in youth male soccer players and they identified decreased strength of the posterior chain hip muscles as a risk factor for lateral ankle sprains. In your study, Gribble et al. [20] wanted to determine which clinical tests, focused on potentially modifiable factors of movement patterns and body mass index, could greater demonstrate risk of ankle sprain among high school and collegiate football players. The result was that Football players who sustained an ankle sprain during the season had lower reaches in the anterior direction of the SEBT and higher body mass index scores before the season began. The reaches in the anterior direction of the SEBT appears to offer the strongest prediction capability.

Porkazemi et al. [21] verified which impairments that differ in participants with a recent index lateral ankle sprain versus participants with no history of ankle sprain. They observed that the performance on the SEBT (anterior direction) and the number of foot lifts during single-legged stance with eyes closed are most strongly discriminated between groups. In another study, Porkazemi et al. [22], developed an exploratory study to find potential predictors of recurrent ankle sprain, in the same groups of anterior study, and they concluded that a combination of factors such as history of a recent index sprain, younger age, greater height and weight, increased number of foot lifts during single-leg balance, increased ligamentous laxity and perceived instability, predicted the occurrence of sprain in $90 \%$ participants. Besides that, greater inversion and eversion peak power were also among the predictors of ankle sprain. Therefore, it is necessary to continued development of a prediction model for ankle sprain risk to establish risk factors is an important step toward the development of effective prevention strategies to decrease this injury in athletic population.

\section{References}

1. Fong DT, Hong Y, Chan LK, Yung PS, Chan KM (2007) A systematic review on ankle injury and ankle sprain in sports. Sports Med 37(1): 73-94.

2. Hootman JM, Dick R, Agel J (2007) Epidemiology of collegiate injuries for 15 sports: Summary and recommendations for injury prevention initiatives. J Athl Train 42(2): 311-319.

3. Zemper ED, Harmer PA (1956) Fencing. In: Caine DJ, Caine CJ, Lindner KJ (Eds.), Epidemiology of sports injuries. Champaign, Human Kinetics, USA.

4. Harmer PA (2008) Getting to the point: injury patterns and medical care in competitive fencing. Curr Sports Med Rep 7(5): 303-307.

5. Konradsen L, Bech L, Ehrenbjerg M, Nickelsen T (2002) Seven years follow-up after ankle inversion trauma. Scand J Med Sci Sports 12(3): 129-135. 
6. Anandacoomarasamy A, Barnsley L (2005) Long-term outcomes of inversion ankle injuries. Br J Sports Med 39(3): e14.

7. Hupperets MD, Verhagen EA, Heymans MW, Bosmans JE, van Tulder MW, et al. (2010) Potential savings of a program to prevent ankle sprain recurrence: economic evaluation of a randomized controlled trial. Am J Sports Med 38(11): 2194-2200.

8. Hiller CE, et al. (2012) Prevalence and impact of chronic musculoskeletal ankle disorders in the community. Arch Phys Med Rehabil 93(10): 18011807.

9. Verhagen, van der Beek A, Twisk J, Bouter L, Bahr R, et al. (2004) The effect of a proprioceptive balance board training program for the prevention of ankle sprains: a prospective controlled trial. Am J Sports Med 32(6): 1385-1393.

10. Hiller CE, Kilbreath SL, Refshauge KM (2011) Chronic ankle instability: Evolution of the model. J Athl Train 46(2): 133-141.

11. Hjelm N, Werner S, Renstrom P (2010) Injury profile in junior tennis players: A prospective two year study. Knee Surg Sports Traumatol Arthrosc 18(6): 845-850.

12. de Noronha M, Franca LC, Haupenthal A, Nunes GS (2013) Intrinsic predictive factors for ankle sprain in active university students: A prospective study. Scand J Med Sci Sports 23(5): 541-547.

13. De Ridder R, Witvrouw E, Dolphens M, Roosen P, Van Ginckel A (2017) Hip strength as an intrinsic risk factor for lateral ankle sprains in youth soccer players: a 3-season prospective study. Am J Sports Med 45 (2): 410-416.

14. Trojian TH, McKeag DB (2006) Single leg balance test to identify risk of ankle sprains. Br J Sports Med 40(7): 610-613
15. Willems T, Witvrouw E, Delbaere K, De Cock A, De Clercq D (2005) Relationship between gait biomechanics and inversion sprains: A prospective study of risk factors. Gait Posture 21(4): 379-387.

16. Hadzic V, Tine S, Eva T, Zoran J, Helena B, et al. (2009) Risk factors for ankle sprain in volleyball players: A preliminary analysis. Isokinet Exerc Sci 17(3): 155-160

17. Plisky PJ, Rauh M, Kaminski T, Underwood F (2006) Star excursion balance test as a predictor of lower extremity injury in high school basketball players. J Orthop Sports Phys Ther 36(12): 911-919.

18. Attenborough AS, et al. (2017) The identification of risk factors for ankle sprains sustained during netball participation. Phys Ther Sport 23: $31-$ 36.

19. Hertel J, Braham RA, Hale SA, Olmsted-Kramer LC (2006) Simplifying the star excursion balance test: Analyses of subjects with and without chronic ankle instability. J Orthop Sports Phys Ther 36(3): 131-137.

20. Gribble PA, Terada M, Beard MQ Kosik KB, Lepley AS, et al. (2016) Prediction of lateral ankle sprains in football players based on clinical tests and body mass index. Am J Sports Med 44(2): 460-467.

21. Pourkazemi F, Hiller C, Raymond J, Black D, Nightingale E, et al. (2016) Using balance test $\mathrm{s}$ to discrim inate between participant $\mathrm{s}$ with a recent index lateral ankle sprain and healthy control participant s: a crosssectional study. J Athl Train 51(3): 213-222.

22. Pourkazemi F, Hiller CE, Raymond J, Black D, Nightingale EJ, et al. (2017) Predictors of recurrent sprains after an index lateral ankle sprain: a longitudinal study. Physiotherapy pii: S0031-9406(17)30093-7.
Creative Commons Attribution 4.0

International License

For possible submissions Click Here

\section{Submit Article}

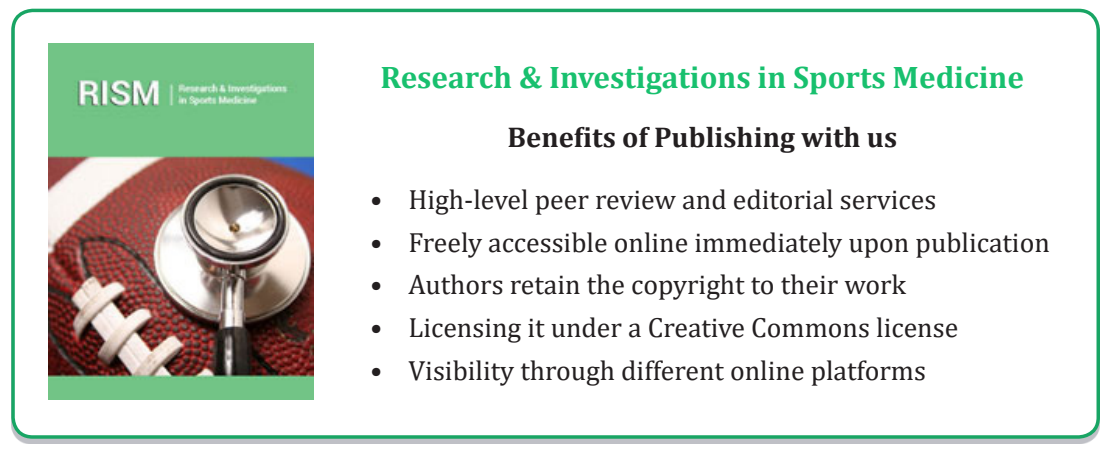

